\title{
Objectives of Sustainable Development and Analysis of People's Economy Improvement
}

\author{
Bachtari Alam Hidayat ${ }^{1, *}$, Evi Yuliana ${ }^{2}$, Baskoro Wicaksono ${ }^{3}$, Kusmawaty Matara ${ }^{4}$, \\ Afriyanni $^{5}$, Sekar Nur Wulandari ${ }^{6}$, Nanda Hasanul Amri ${ }^{7}$, Herie Saksono ${ }^{8}$ \\ ${ }^{1}$ Development Planning, Research and Development Agency of Palembang City, 30131 and Pascasarjana Universitas \\ Tamansiswa Palembang, South Sumatera Province, 30126, Indonesia. \\ ${ }^{2}$ Development Planning, Research and Development Agency of Palembang City, South Sumatera Province, 30131, Indonesia. \\ ${ }^{3}$ Universitas Riau, Riau Province, 28293, Indonesia. \\ ${ }^{4}$ Institut Agama Islam Negeri (IAIN) Sultan Amai Gorontalo, Gorontalo, 96114, Indonesia. \\ ${ }^{5}$ Research and Development Agency of Pekanbaru City, Riau Province, 28285, Indonesia. \\ ${ }^{6}$ Planning, Research and Development Agency of Riau Islands Province, 29124, Indonesia. \\ ${ }^{7,8}$ Research \& Development Agency of the Ministry of Home Affairs of the Republic of Indonesia, Jakarta, 10430, Indonesia. \\ *Corresponding author E-mail: alamhidayat79@gmail.com
}

\begin{abstract}
The Sustainable Development Goals (SDGs) are defined as development goals which ensure that the community's economic wellbeing is improved, social life is sustained, the environment's quality is maintained, and justice and good governance are properly implemented. These goals prescribed by the United Nations ultimately aim to increase the standard of living from one generation to another. The SDGs represent a global and national commitment to enhancing community wellbeing. Efforts to fulfill the SDG targets are a national development priority, requiring a synergy of national, province, district, and municipal planning strategies. Poverty continues to be a concern in a number of countries throughout the world, including in Indonesia, particularly in the city of Palembang, making poverty reduction a goal of the sustainable development agenda. Poverty alleviation, which was the primary objective of the Millennium Development Goals (MDGs), is once again the primary objective of the SDGs. The problem of poverty is framed within a multidimensional framework, which includes examining poverty from a variety of perspectives and examining the causes of poverty from a variety of angles. The research approach entails conducting interviews, conducting a Strength-Weakness-Opportunity-Threat (SWOT) Analysis, and conducting a literature study. According to the SWOT analysis findings, opportunities include the following: the growth of digital marketing, and increased consumption of products and services benefit the development of micro and small enterprises by allowing them to expand their production capacity. Threats include the Covid-19 pandemic and intense business competition; strengths include the majority of impoverished entrepreneurs; weaknesses include insufficient coordination of poverty reduction efforts across institutions. To address these issues, the Palembang City Government implemented policies to strengthen the local economy by (1) allocating budget resources to support business capital assistance and assistance programs for startup businesses and MSME actors, (2) developing financial institutions at the Kelurahan, RW, and RT levels, and (3) initiating training and mentoring programs for local economic development. By establishing a people's economy, it will foster equitable economic growth based on innovation and creativity, as well as a high level of competitiveness driven by the community, while also lowering the poverty rate.
\end{abstract}

Keywords: SDGs, poverty, and the people's economy

\section{INTRODUCTION}

The 2015 Millennium Development Goals (MDGs) serve as a roadmap for attaining sustainable development and a better future for everybody by collaborating to address the planet's difficulties. ${ }^{1}$ Poverty is still a concern in every country's development, and it is used as a metric for determining a country's level of wellbeing. The diminishing percentage of the poor population can be a reflection of a country's high level of welfare. ${ }^{2}$ Even after the MDGs were completed, the Sustainable Development Goals (SDGs) included a development target of zero poverty in whatever form. ${ }^{3}$ The SDGs were adopted by the United Nations General Assembly and entered into force in January 2016 as a result of agreement by leaders of wealthy and developing countries to pursue two major anthropocentric visions: increasing human prosperity and rights and conserving the planet. According to analysts, the SDGs face a number of pressing issues, including technological innovation, the role of businesses in poor nations, non-financial reporting, and 
education. ${ }^{4}$ The SDGs are a critical component of numerous national development programs and foreign aid agenda. ${ }^{5}$ The United Nations SDGs are an urgent demand for all countries to establish a worldwide framework for global development while preserving social, economic, and environmental balance. $^{6}$

The United Nations General Assembly adopted the SDGs to promote the operationalization and integration of sustainability organizations in order to address current and future stakeholder needs and to ensure a more just and sustainable future for all, while balancing economic, social, and environmental development. ${ }^{7}$ With only ten years remaining to fulfill all of the SDGs internationally, there is an increasing demand for action effectiveness and efficiency. ${ }^{8}$ The SDGs present a significant challenge for developing countries, including Indonesia. ${ }^{9}$ Indonesia, although being a developing country with a middle income status, nonetheless has a significant percentage of poverty. In general, the poverty rate in Indonesia has decreased in both number and percentage terms from 1999 to 2017. In both absolute and relative terms, the reduction in poverty that has occurred may be recognized. Although poverty in general has decreased, the percentage of poverty is still in the double digits and conditions of low welfare levels and high poverty rates occur in almost all provinces outside Java.

Palembang City as the capital of South Sumatra Province is the second largest city on Sumatra Island, after Medan City. Palembang City's economy continues to rise year after year, with a 5.94 percent increase in $2019 .{ }^{10}$ The source of economic growth came from the Wholesale and Retail Trade, Car and Motorcycle Repair Sector which grew by 1.39 percent; the Manufacturing Sector by 1.18 percent, and; the Construction Sector by 0.96 percent. ${ }^{11}$ In line with the increase in economic growth, the number of poor people in Palembang City is still quite high, although its percentage of the total population has decreased. Similarly, global poverty has been steadily declining over the previous few decades. ${ }^{12}$ In 2014, the number of poor people was 202.31 thousand people or 12.98 percent of the total population, then decreased in 2019 to 180.70 thousand people or 10.90 percent of the total population. ${ }^{11}$ In order to address these problems, realizing citizen potential in the global data ecosystem, fostering collaboration around citizen data science in order to accelerate SDG achievement, and leveraging investments to boost use and effect. ${ }^{13}$

By and large, the majority of economic activities are intended to benefit industrialization, infrastructure, and innovation [SDGs 9] and economic productivity [SDGs 8], but many also contribute to meeting fundamental necessities [SDGs 2, 3, 4, 6, 7, 11]. ${ }^{14}$ Numerous participative and demand-driven techniques have evolved in response to the multifaceted nature of poverty in emerging nations. ${ }^{15}$ The trade and industrial sector is an important business sector in a city, including the city of Palembang, which continues to be supported by innovation in the application of technology that continues to be increasingly sophisticated and fast, one of which is creative souvenirs/crafts. In addition, the great potential in the food/culinary processing industry originates from local economic development activities, which are regional businesses in spurring economic development and are expected to provide benefits to the community as a whole.

Basically, the development carried out aims to improve the welfare of the community. ${ }^{5}$ Poverty reduction efforts through the empowerment of Micro, Small and Medium Enterprises (MSME) are a continuous effort where this process will always be developed with various improvements and refinements in all aspects of empowering MSME from time to time. In order to evaluate the effectiveness of the program to improve the people's economy, especially MSME, an assessment is needed so that more effective policies and strategies can be produced in the future. ${ }^{16}$

\section{METHOD}

The research method uses interviews, SWOT analysis, and literature review. Interviews were conducted to identify the types of community entrepreneurs. Through the SWOT analysis, an understanding of the opportunities, threats, strengths and weaknesses in poverty alleviation in Palembang City is obtained. Followed by a literature review related to the characteristics of poverty, the causal factors, and strategies for overcoming them.

\section{RESULT AND DISCUSSION}

As many as 7,691 poor persons work as entrepreneurs (including micro and small firms), accounting for $17.47 \%$ of the overall poor. Various enterprises which employ 3,101 people, and the home industry which employs 1,547 people are the most prevalent business fields. In the food, apparel, and leather industries, as well as handicraft enterprises, nonformal small industries accounted for 47 percent of their business units in 2018. Workers in Palembang City's nonformal minor businesses, including food, clothes, and leather, as well as handicraft industries, account for 44 percent of the overall workforce. ${ }^{17}$ Attaining sustainable development is unquestionably a goal shared by all societies and communities. The notion that must be handled is the constant and dynamic aim that an individual wishes to attain, including continuous and consistent measurement. ${ }^{18}$ The 2030 Agenda for Sustainable Development is based on the MDGs and adds a new dimension of sustainability to the development world, most notably through a commitment to resolving global development problems and enabling developing countries to play a significant role in global development. ${ }^{19}$

Self-development through skills acquisition must also be balanced against cultural preservation and the use of indigenous items. ${ }^{3}$ In Palembang, for example, the creative economy sector has proven to be a source of fresh economic strength. In the midst of slowing global commodity and raw 
material prices, the creative economy sector in Palembang City has shown positive activity in the last four years, with the rise of creative craft businesses, particularly related to the development of better and faster communication technology, and sales levels with increasing turnover.

In the meantime, the Palembang culinary economy sector has been growing steadily since 2017 . This can be observed in the Gross Regional Domestic Product (GRDP) growth rate by Business Field, which shows that the processing sector ranks top as a contributor to GRDP; the processing industry in issue being the food processing industry and culinary items.

To actualize the development of the people's economy, the Palembang City Government must adopt policies that promote these two areas. A SWOT analysis was conducted as part of the strategy development:

Opportunities: 1. The level of public consumption in the domestic market, both nationally and regionally, tends to rise every year, contributing the most to the formation of GRDP on the basis of expenditure. 2. Domestic and international tourist visits tend to rise, transforming the country into a tourism power. 3. The growth of digital marketing as a tool for promoting products and services 4 . Government strategies in economic recovery as a result of the Covid-19 pandemic.

Threats: 1 . Now and in the future, in the era of the covid19 pandemic. 2. Business competition in the form of items of the same sort, necessitating business actors' innovation and originality.

Strengths: 1 . The poor have enterprises. 2. The existence of Micro and Small Enterprise Support Institutions such as non-bank financial institutions/cooperatives. 3. The availability of traditional and modern markets that can accept the products and services created.

Weaknesses include: 1. A lack of appropriate coordination amongst connected agencies/institutions. 2. A lack of robust poor-supporting institutions. 3. Business players are content if the money from the pempek firm is sufficient to cover their daily needs, so there is no compelling reason to expand the business to a greater scale.

During the Covid-19 pandemic, which has decimated nearly every facet of human life on this planet, the village economic sector has not been spared, which is an area that can alleviate worry by increasing economic growth and national food availability. ${ }^{20}$ To address these issues, the Palembang City Government implemented policies to improve the people's economy by (1) allocating budget funds to support business capital assistance and assistance programs for startup businesses and MSME actors, (2) developing financial institutions at the Kelurahan (urban village), RW (hamlet), and RT (neighborhood) levels, and (3) launching training and mentoring programs for people's economic development, (4) development of MSME and Cooperative centers, (5) development of a traditional market arrangement system into a modern traditional market, (6) launching of the Palembang 4,000 MSME program with unsecured loans of Rp. 3 million rupiah per MSME, and (7) launching of the Digital Palembang program for digital startup business actors. ${ }^{21}$ While rural poverty has been extensively studied on a variety of objective aspects, less emphasis has been paid to establishing poverty lines and subjective poverty, which are dependent on the effectiveness of Targeted Poverty Reduction strategies.22 The findings indicate that IMS studies frequently overlook the governance dimension when examining the sustainability topics of economic growth, social inclusion, environmental protection, and governance. ${ }^{23}$

Palembang is a city that trades in a variety of creative craft products. However, for the sake of the growth of the creative craft business, it obviously requires government support, particularly greater support from the Palembang city government, so that the development of creativity and Creative Craft Innovation in Palembang City can run more quickly, with training and workshops on creative crafts. It is highly sought after by creative craft actors in order to increase creativity and new innovations in order to compete on a global scale. The sustainability of Palembang City's culinary business involves a variety of parties, both from the culinary business actors and other agencies/agencies/institutions, in order to support the development of the creative economy in the culinary tourism sector in Palembang City in a sustainable manner, which has an impact on increasing people's income, empowering employment, and increasing public welfare. By realizing a people's economy, equitable economic growth based on innovation and creativity will be generated, as well as high competitiveness driven by the community, while decreasing the percentage of the poor. ${ }^{24,25}$

Globally, achieving sustainable development involves multidisciplinary efforts and viewpoints. Global objectives influence priorities and activities at many scales, resulting in cascading effects at the local level through the allocation of financial resources and the implementation of progressoriented programs. ${ }^{26}$ Alternative strategies are required to address these issues, one of which is to engage the business community in ways that are consistent with the purpose of attaining the SDGs, thereby assisting the government in accelerating its achievement of the SDGs. ${ }^{27}$ A tailored Multidimensional Poverty Framework (MPF) comprises fifteen indicators addressing critical dimensions of poverty such as income, basic necessities, health, education, and the environment. Our findings show that the current financial difficulties confronting a large number of low-income nations may reverse recent progress toward poverty reduction. The financial crisis has been attributed to an increase of approximately $10 \%$ in extreme poverty in lowincome countries. The effect is considerably more pronounced in several other elements of poverty. ${ }^{28}$ The SDGs were proposed by the United Nations General 
Assembly and came into force in January 2016 as a result of agreement between developed and developing country leaders in their efforts to achieve two major anthropocentric visions, namely promoting human prosperity and rights and protecting the planet. $^{29,30}$ In some cases, there are often discrepancies between the results of government performance and the reality of human development, economic growth, and inequality in income distribution. ${ }^{31}$ The primary goal of development is to enhance the community's welfare and prosperity. Meanwhile, "Sustainable development" is defined as "development that meets the needs of the current generation without jeopardizing future generations' ability to meet their own, and that sustainable development aims to improve people's welfare, to meet human needs and aspirations" and also Using jargons such as free and fair trade, they instructed many countries, both developed and developing ones. ${ }^{18,32}$

\section{CONCLUSION}

The SDGs are defined as development goals which ensure that the community's economic well-being is improved, sustainably, development that ensures the community's social life is sustained, development that ensures the environment's quality is maintained, and development that ensures justice and good governance are properly implemented. These goals prescribed by the United Nations ultimately aim to increase the standard of living from one generation to another. Through the SDGS, realizing a people's economy will generate equitable economic growth based on innovation and creativity, as well as high competitiveness driven by the community, while decreasing the percentage of the poor.

\section{REFERENCES}

[1] Echendu, Adaku Jane. 2020. The Impact Of Flooding On Nigeria's Sustainable Development Goals (Sdgs). Ecosystem Health And Sustainability, Vol. 6, No. 1, 1791735.

Https://Doi.Org/10.1080/20964129.2020.1791735

[2] Panjawa J1, Trianto J. 2020. Peran Pembangunan Manusia Dan Desentralisasi Terhadap Kemiskinan Melalui Pertumbuhan Ekonomi. Gorontalo Development Review (Golder). Vol. 3 No. 1, P 39-47

[3] Ruslan D. 2016. Evaluasi Millenium Development Goals (Mgds) Dalam Menanggulangi Kemiskinan Dan Kelaparan Menuju Sustainable Development Goals (Sdgs) Di Kota Medan. Qe Journal Vol. 05 - No. 03, P 130-148

[4] Pizzi, Simone. 2020. Management Research And The Un Sustainable Development Goals (Sdgs): A Bibliometric Investigation And Systematic Review. Journal Of Cleaner Production
[5] Moyer, Jonathan D. 2020. Are We On The Right Path To Achieve The Sustainable Development Goals? World Development127 104749

[6] Mio, Chiara. 2020. Sustainable Development Goals And The Strategic Role Of Business: A Systematic Literature Review. Bus Strat Env. 2020;1-26 Doi: 10.1002/Bse. 2568

[7] Fraisl, Dilek. 2020. Mapping Citizen Science Contributions To The Un Sustainable Development Goals. Sustainability Science 15:1735-1751 Https://Doi.Org/10.1007/S11625-020-00833-7

[8] Scharlemann, Jörn P. W. 2020. Towards Understanding Interactions Between Sustainable Development Goals: The Role Of Environment-Human Linkages. Sustainability Science 15:1573-1584 Https://Doi.Org/10.1007/S11625-020-00799-6

[9] Sofianto, Arif. 2019. Integrasi Target Dan Indikator Sustainable Development Goals (Sdgs) Ke Dalam Perencanaan Pembangunan Daerah Di Jawa Tengah Jurnal Litbang Provinsi Jawa Tengah, Volume 17 Nomor 126

[10] BPS Kota Palembang. PDRB Menurut Pengeluaran 2019, Publikasi Online, 2020

[11] BPS Kota Palembang. Stratistik Kesejahteraan Rakyat Tahun 2019, Publikasi Online, 2020

[12] Wietzke, Frank-Borge. 2020. Poverty, Inequality, And Fertility: The Contribution Of Demographic Change To Global Poverty Reduction Population And Development Review 46(1): 65-99 (March)

[13] Luis Miguel Fonseca. 2020. Mapping The Sustainable Development Goals Relationships. Sustainability, 12, 3359; Doi:10.3390/Su1208335926

[14] Zanten, Jan Anton Van. 2021. Towards Nexus-Based Governance: Defining Interactions Between Economic Activities And Sustainable Development Goals (Sdgs). International Journal Of Sustainable Development \& World Ecology, Vol. 28, No. 3, 210-226 Https://Doi.Org/10.1080/13504509.2020.1768452

[15] Singh, Pramod K. 2020. Evaluating Poverty Alleviation Strategies In A Developing Country. Plos One Https://Doi.Org/10.1371/Journal.Pone.0227176 January 13

[16] Astria, Sally. 2018. "Kampung Kuliner Palembang Di Sumatera Selatan”. Universitas Atma Jaya Yogyakarta.

[17] BPS Kota Palembang. Profil Kemiskinan Kota Palembang, 2018, Publikasi Online, 2020

[18] Ivković, Anita Frajman. 2014. Measuring Objective Well-Being And Sustainable Development Management. Scientific Papers (Www.Scientificpapers.Org) Journal Of Knowledge 
Management, Economics And Information Technology. Vol. Iv, Issue 2, April

[19] Yu, Siming. 2020. Adoption And Implementation Of Sustainable Development Goals (Sdgs) In ChinaAgenda 2030. Sustainability, 12, 6288; Doi:10.3390/Su12156288

[20] Karim, Abdul. 2020. Improvement Of Rural Economy Natural Movements Supporting Urban Economic Growth In Global Pandemic Period

[21] Bapeda Palembang. Rencana Pembangunan Jangka Menengah (Rpjk) Kota Palembang, 2018-2023, Publikasi Online, 2019

[22] Wang, Hanjie. 2020. Poverty And Subjective Poverty In Rural China. Social Indicators Research 150:219242 Https://Doi.Org/10.1007/S11205-020-02303-0

[23] Rasoolimanesh, S. Mostafa. 2020. A Systematic Scoping Review Of Sustainable Tourism Indicators In Relation To The Sustainable Development Goals. Journal Of Sustainable Tourism 1-21 Https://Doi.Org/10.1080/09669582.2020.1775621

[24] Hidayat BA. 2021. Stunting And Poverty Management Strategies In The Palembang City, Indonesia. Randwick International Of Social Science (Riss) Journal. Vol.2 No. 1 P 86-99

[25] Hidayat BA. 2021. Stunting And Poverty Management Strategies In The Palembang City, Indonesia. Randwick International Of Social Science (Riss) Journal. Vol.2 No. 1 P 86-99

[26] Sterling, Eleanor J. 2020. Creating A Space For Place And Multidimensional Well-Being: Lessons Learned From Localizing The Sdgs. Sustainability Science 15:1129-1147 Https://Doi.Org/10.1007/S11625-02000822-W
[27] Sudirman, Faturachman Alputra. 2021. Corporate Social Responsibility (Csr) Contribution To Achieve Sustainable Development Goals (Sdgs) In Southeast Sulawesi. Proceedings Of The 11th Annual International Conference On Industrial Engineering And Operations Management Singapore, March 7-11

[28] Antoniades, Andreas. 2021. Financial Crises And The Attainment Of The Sdgs: An Adjusted Multidimensional Poverty Approach. Sustainability Science $15: 1683-1698$ Https://Doi.Org/10.1007/S11625-019-00771-Z

[29] Lim, Seng Boon. 2021. Sdgs, Smart Urbanisation And Politics: Stakeholder Partnerships And Environmental Cases In Malaysia. Journal Of Sustainability Science And Management Volume 16 Number 4, June: 190-219

[30] Apriliani RPA. 2018. Pengentasan Kemiskinan di Desa Talok Melalui Pendidikan Non Formal Berbasis Anyaman Bambu dengan Metode Pembangunan Berkelanjutan Pasal 7 UU No. 13 Tahun 2011 Menuju Sustainable Development Goals (SDGs) di Indonesia 2045. Lex Scientia Law Review. Volume 2 No. 1, p 31 46

[31] Saksono, Herie. 2016. New Faces of Regional Autonomy: Status of Performance versus Realistic Conditions in the Region of Province of South Kalimantan. Jurnal Kebijakan Pembangunan. Vol. 11 Nomor 2, Desember 2016: 133-148

[32] Bimantara, A. 2019. Donald Trump's Protectionist Trade Policy from the Perspective of Economic Nationalism. Jurnal Hubungan Internasional, 7(2), 189 204. 